Olga Chunakova

\title{
Middle Iranian Manichaean manuscripts. Interpretation and identification*
}

Abstract: The present paper provides an interpretation of the Parthian fragment SI 5576 belonging to the Serindian Collection of the Institute of Oriental Manuscripts, Russian Academy of Sciences. The poorly preserved text is a hymn dedicated to Wisdom and, perhaps, is an adaptation of a Mandaean text. Its contents suggest that it was performed during the Bema, the main Manichaean holiday. The fragment's paper, ink, handwriting, and the Chinese text on the recto side show that it is part of the same manuscript as the fragment M 4590 belonging to the Berlin Turfan Collection, and that the manuscript seems to have been a list of hymns to be performed during the Bema holiday.

Key words: Manichaeism, Manichaean literature, Parthian language, Turfan texts

\section{Introduction}

The Middle Iranian Manichaean manuscripts belonging to the St. Petersburg Collection comprise about one hundred fifty manuscript fragments in the Middle Persian, Parthian and Sogdian languages in Manichaean and Sogdian script. While some of these writings consist of nearly intact leaves, most of them are very small fragments: the St. Petersburg Collection contains no complete codex or scroll. The fragmentary character of this material, together with the fact that some of the missing pieces are often kept in other collections, raises fundamental problems in understanding what we are dealing with. Besides having a solid knowledge of the collections which are taken into consideration as well as of the history of the phenomena that produced the material under investigation, a combination of codicological, palaeographical, philological and linguistic skills is required.

(C) Olga Mikhailovna Chunakova, Institute of the Oriental Manuscripts, Russian Academy of Sciences, St. Petersburg (ochunakova@inbox.ru).

* I am very grateful to Dr. Chiara Barbati for a careful reading of the article and making useful suggestions and comments. 
From the point of view of material aspects, the present contribution is aimed at demonstrating that two fragments - one belonging to the St. Petersburg Collection, i.e. SI 5576, and the other one belonging to the Berlin Turfan Collection, i.e. M 4590, — are part of the same manuscript.

From the point of view of literary aspects, the kind of text which is preserved in these two fragments will be discussed. Particular attention will be devoted to the purposes of the use and to the user.

\section{The fragments SI 5576 and M 4590}

The fragment SI 5576 belongs to the St. Petersburg Collection. Its dimensions are $8.7 \times 12.7 \mathrm{~cm}$. It is part of a scroll: it is well known that many Manichaean texts were written on the verso side of re-used Chinese scroll. ${ }^{1}$ The recto side contains 5 writing lines in Chinese language corresponding to Taishō Tripitaka, vol. 15, sutra 614, p. 274b, 1l. 1-5. ${ }^{2}$ The verso side contains 13 writing lines and, in turns, each writing line consists of about 45 letters. The size of the letters is circa $0.2 \mathrm{~cm}$ and the line spacing is $0.6 \mathrm{~cm}$. Only the inner margin is partially preserved. The finding place of this fragment is unknown. The fragment is written on paper. The text is written in black iron gall ink that contains chemical elements leading to the oxidization and the consequent destruction of the paper. ${ }^{3}$ SI 5576 is written in cursive. Besides, the fragment was at some moment restored and glued onto tracing paper. ${ }^{4}$ In so doing, the tears have been badly aligned with the lines and some letters have overlapped making the reading more difficult.

The fragment M 4590 (T II D 31) belongs to the Berlin Turfan Collection and is available online at $\mathrm{http} / / /$ turfan.bbaw.de/dta/m/images $/ \mathrm{m} 4590$ recto.jpg. The dimensions of the fragment are: $10.8 \times 12.7 \mathrm{~cm}$. The fragment includes part of a margin. According to M. Boyce, the fragment was found in Khočo. ${ }^{5}$ It was part of a scroll. M 4590 (T II D 31) is written on paper. One side shows a Chinese text corresponding to Taishō Tripiṭaka, vol. 15, sutra 614,

\footnotetext{
${ }^{1}$ For more information on the Manichaean scrolls see GULÁCSI 2005, 88-91.

${ }^{2}$ Identified by Viacheslav Zaytsev, the researcher of the Institute of Oriental Manuscripts, Russian Academy of Sciences, whom I am deeply grateful.

${ }^{3}$ I thank Liubov Kriakina, the leading artist-restorer of the Institute of Oriental Manuscripts, Russian Academy of Sciences, for this information.

${ }^{4}$ According to Liubov Kriakina, restoration could have been done at the Institute in the late forties - early fifties.

${ }^{5}$ See Boyce 1960, XXXIII.
} 


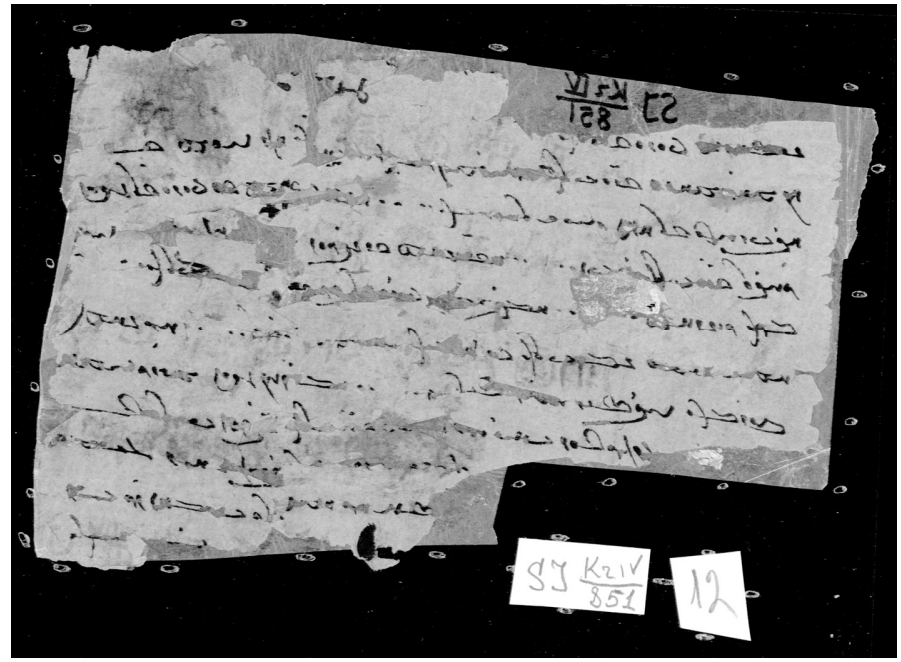

Pl. 1.

Collection of IOM RAS, SI 5576 verso

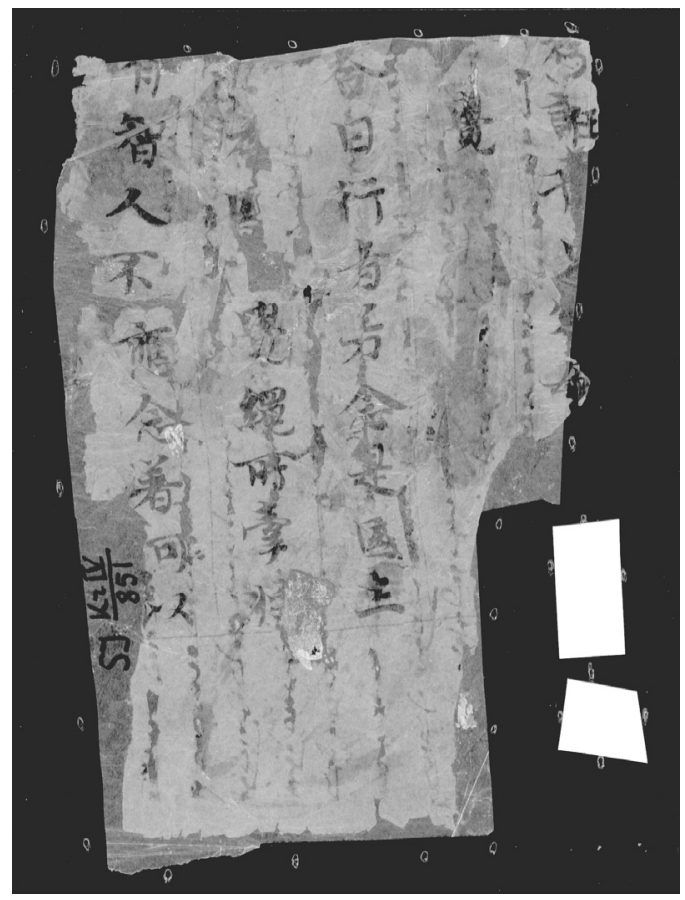

Pl. 2.

Collection of IOM RAS, SI 5576 recto 
p. 274b, 11. 13-17, ${ }^{6}$ and the other side contains 13 writing lines in the Parthian language - including some Middle Persian words - in Manichaean script. The text is written in black ink. The height of letters is $0.2 \mathrm{~cm}$, line spacing is $0.6 \mathrm{~cm}$.

Due to paleographical reasons, it seems to me that the fragment SI 5576 and the fragment M 4590 have been written in the same handwriting, with the same shape and size of the letters, and that they belong to the same manuscript. If SI 5576 and M 4590 belong to the same manuscript, and, as we have seen, M 4590 was found in Khočo, we can assume that SI 5576 was also found in Khočo.

\section{Devotion to Wisdom and Bema feast}

The fragment SI 5576 belonging to the St. Petersburg collection contains about 45 legible words including prepositions $p d$, ' $w$, ' $c$, copula ' $w d$ and relative pronoun $c y$ used to express attribution. The first sentence of the text (11. 4-5) contains the name Mani, the founder of the Manichaean religion: ' $z$ m'ry m'ny fryštg "I, Lord Mani, the messenger (or: apostle)". Further (1. 4), the name 'whrmyzdbg, i.e. the First Man of the Iranian Manichaean Iranian texts is legible, then the verbal form 'gd hym "I arrived" (1st person singular) and the expression $p d$ ' $x \check{s} d^{\prime}$ 'gyft ' $c$ whyšt "from the paradise with grace". The next passage (11. 5-6) shows a period represented with two double-dots contains about 10 illegible letters and ends with the words $p d$ jyryft cy w'xt fryštg rwšn "the wisdom pronounced by the Messenger of light (i.e. Mani)". The sixth and the seventh writing lines contain three subjunctive verbs (1st person plural): 'fryn'm "let us praise", bwg wynd'm "let us find salvation" and 'bxrws' $m$ jyryft "let us glorify the wisdom". The imperative verbal form 'zgwlyd "you, listen!" occurs in the tenth writing line. The eighth line shows about ten missing letters and a very legible verbal form, i.e. the participle nbyštg "written". The ninth-eleventh lines show a clear Manichaean terminology: qyrbg "piety", rwšn "light", r'z cy $m r d w h m$ 'n "mystery of humans" - known to have been revealed to the people by Mani who declared that light was inside the matter - and the noun šwb'n "shepherd".

\footnotetext{
${ }^{6}$ I thank Viacheslav Zaytsev for this identification.

${ }^{7}$ I would like to thank Prof. D. Durkin-Meisterernst for helping in reading the Petersburg fragment SI 5576. For the publication of the fragment see CHUNAKOVA 2015, 59-64.
} 


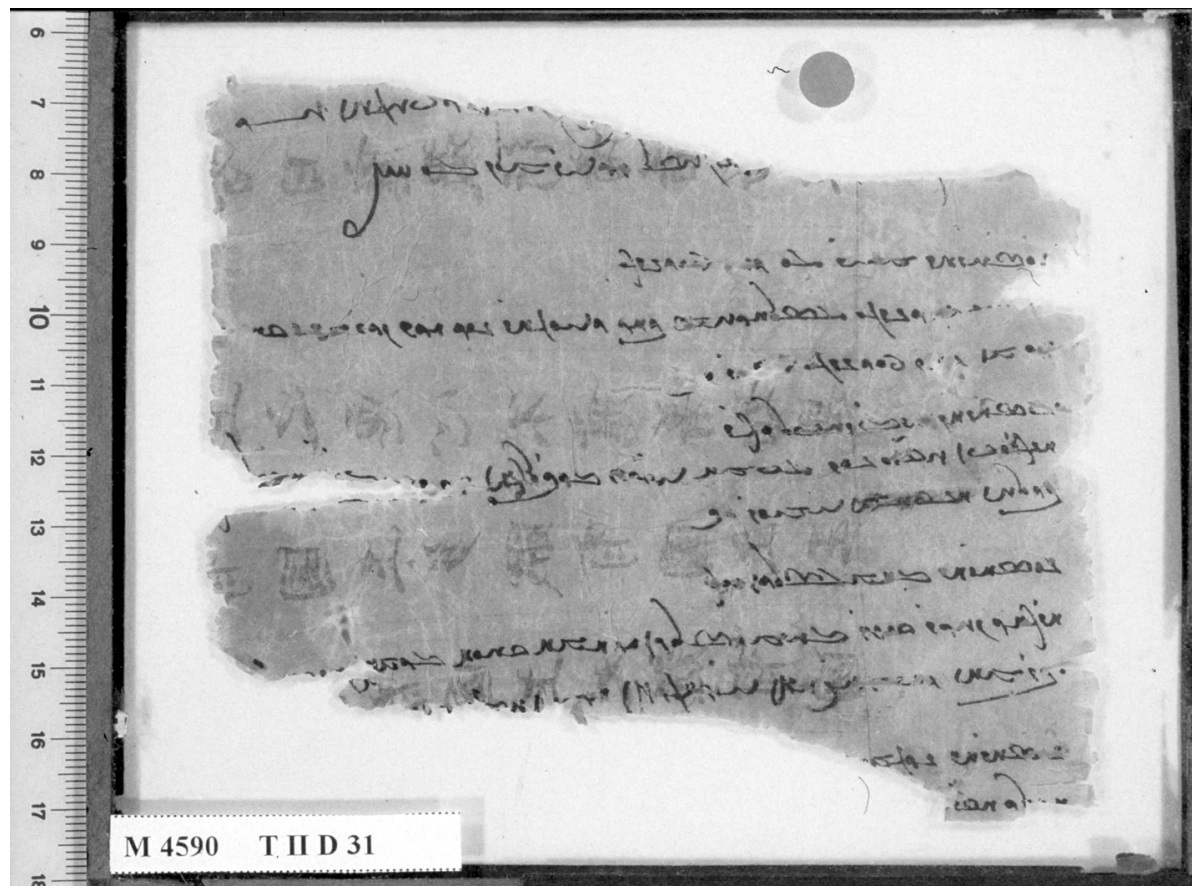

Pl. 3.

Depositum der

BERLIN-BRANDENBURGISCHEN AKADEMIE DER WISSENSCHAFTEN in der

STAATSBIBLIOTHEK ZU BERLIN — Preussischer Kulturbesitz Orientabteilung M 4590 (T II D 31) verso 


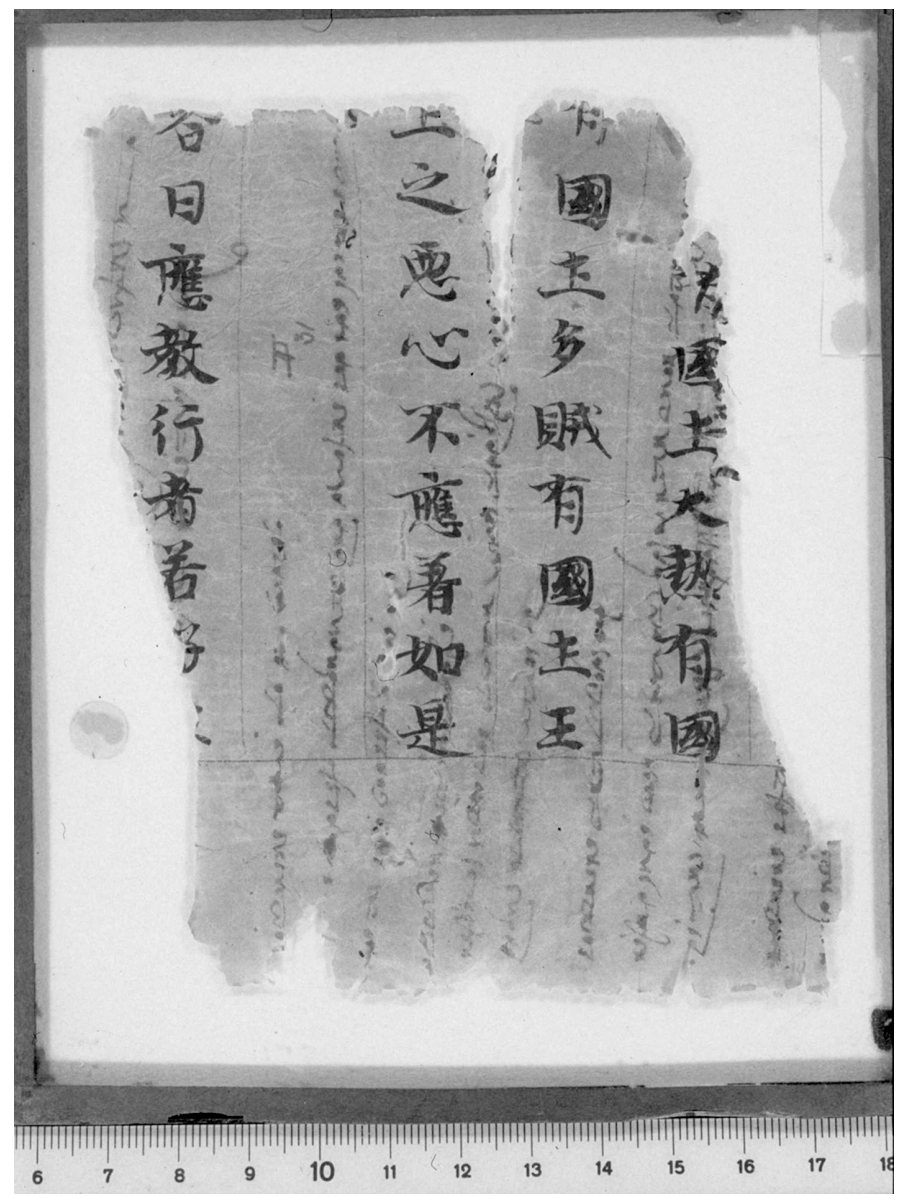

Pl. 4.

Depositum der

BERLIN-BRANDENBURGISCHEN AKADEMIE DER WISSENSCHAFTEN in der

STAATSBIBLIOTHEK ZU BERLIN — Preussischer Kulturbesitz Orientabteilung M 4590 (T II D 31) recto 
The word jyryft "wisdom" can be found twice (11. 5 and 7) in the fragment SI 5576. The third line, i.e. the first preserved one contains a passive participle and the adjective jyryftyg formed by the noun jyryft and the most common suffix for forming adjectives from nouns - yg: nys'r'd jyryftyg, i.e. "begun is the (hymn) (dedicated) to Wisdom". This phrase was a standard formula preceding the text of a hymn in Manichaean manuscripts.

The text preserved in the fragment SI 5576 should be considered prosaic as it does not show any of the peculiarities belonging to poetry: no alphabetical order of the passages, no blank lines, the words are not broken into syllables and they are not provided with the final vowel ' $[\bar{a}]$ indicating that the word should be sung. Nevertheless, it was meant to be read during a liturgy. The proof can be found in the structure of the text. The phrase ascribed to Mani (11. 4-5) is followed by the words that a priest uses to address to the audience: 'fryn'm "let us praise", bwg wynd'm "let us find salvation", 'bxrws'm jyryft "let us glorify the Wisdom", 'zgwlyd "listen!".

The statement that Mani descended from the paradise (11. 4-5) is a direct indication to the purpose of the text: it was evidently read during the main Manichaean feast commemorating Mani's death. ${ }^{8}$ Celebrated extremely solemnly, that feast took place in March and was called "Bema" in Greek (literally "throne, altar"). That Greek word is common in Iranian Manichaean texts along with Middle Persian and Parthian $g^{\prime} h{ }^{9}$ and Sogdian $c^{\prime} y d^{\prime} n{ }^{10}$ The name was derived from a special seat, a throne, upon which Mani's portrait was placed. During the feast, the congregation appealed to Mani begging for the remission of the sins they had committed, and addressed to the Gods, Mani, and other apostles with prayers and songs.

Peculiar is the topic itself: the hymn is devoted to Wisdom. In that respect, this Manichaean hymn seems to be unique because we do not have any other example of a hymn to Wisdom in the Turfan collections, though similar compositions are predominant among the Turfan finds, where many are dedicated to the Father of Greatness, to the Living Spirit, to Jesus, etc. These compositions have been transmitted in multiple copies. However, Wisdom was the basic notion of the Mandaean religion to which belonged Mani's father and Mani himself before breaking with the movement at the age of twelve when he received his first revelation. ${ }^{11}$ The parallels between the

\footnotetext{
${ }^{8}$ See HenNing 1936, 9.

${ }^{9}$ See Durkin-MeISTERERnST 2004, 161.

${ }^{10}$ See Sims-Williams and Durkin-Meisterernst 2012, 63.

${ }^{11}$ See WidENGREN 2001, 45-47.
} 
Manichaeans and the Mandaeans as expressed in their myths, ideology, terminology, and rituals are well known. ${ }^{12}$ Moreover, at the end of the tenth line we can read the name $\breve{S y t y l}$ which is the Mandaean rendering of the name $S e t h,{ }^{13}$ a righteous man known from the apocryphal Christian tradition and considered an apostle by the Manichaeans.

In all published Middle Iranian Manichaean Turfan fragments the name of this apostle is mentioned only three times: once, in the fragment M 1859, a Western Iranian cosmogonic hymn; ${ }^{14}$ the second time, in the Middle Persian version of the famous Manichaean canon "The Book of Giants" containing the list of the apostles-šytyl, zrdrwšt, bwt, mšyh' (Šitî̀l, Zarathushtra, Buddha, Christ) ${ }^{15}$ and, finally, in the Sogdian hymn M 5264. ${ }^{16}$ It is also mentioned in two unpublished texts: in the Sogdian M 1071 and in the Parthian M 32b (A). ${ }^{17}$ Besides, the mention of the Mandaean book Qolasta in the unreleased Sogdian colophon to the Parthian text in the manuscript M 481 confirms the existence of contacts between the Mandaeans and the Manichaeans. ${ }^{18}$ For all these reasons, it is quite possible that this Parthian hymn is a translation of a Mandaean original text.

Of course, there is another point of view suggesting that Mani had grown up among the Judaeo-Christian Elchasaites. ${ }^{19}$ Nevertheless, the influence caused by multiple religious movements existing in the Prophet's native land, Southern Babylonia, over the Manichaeans is undeniable.

Deserving attention is the expression ' $z$ m'ry m'ny "I, Lord Mani". The honorific mar (Parthian $m^{\prime} r$, m'ry from Aramaic m'ry, literary "my Lord") would not have been used by Mani himself: ${ }^{20}$ this circumstance suggests a later dating for the composition.

In the second line of the fragment SI 5576, the letter sade [c] is legible and is followed by a few missing letters. The bottom part of the last letter

12 See Widengren 2001, 20-42.

${ }^{13}$ See SMagina 2011, 370.

${ }^{14}$ See SUNDERMANN 1973, 77.

${ }^{15}$ See HenNing 1943, 58, 63 (A 153-154).

${ }^{16}$ See Morano 2017, 174-176.

${ }^{17}$ I thank Dr. E. Morano for this information (e-mail 25.09.2015).

${ }^{18}$ For this information (by e-mail 25.09.2015) I would also like to thank Dr. E. Morano. Besides, on the role that Aramaic and other languages have played by written down Iranian Manichaean psalms and hymns, see REITZENSTEIN 1921, 261; DuRKIN-MEISTERERnST 2004a, 95-107; DURKIN-MEISTERERNST 2007, 59-74.

${ }^{19}$ See Khosroyev 2007, 109-112.

${ }^{20}$ See Boyce 1975, 51, note 6. According to Dr. E. Morano (e-mail 25.09.2015), this phrase can be a quote from the initial lines of the Living Gospel. 
could be that of the final $n$. It seems to me that $c$ is placed aside, away from the beginning of the writing line and that it is written in a different handwriting, as letters are a little bigger and their slope is smaller. The position of the word precludes the idea that it is a title or the final word of a preceding text, so it is possible that here we see a note written by the copyst for his own use. A logical suggestion is that the word may be read as c'yd'n which was a Sogdian term denoting the feast of the Bema when the liturgy was to be served. As already demonstrated by Prof. N. Sims-Williams in analyzing a Sogdian manuscript fragment kept in the Petersburg Collection, ${ }^{21}$ we have texts that should have been read during the Bema fest. If my reading is correct, a Sogdian word is attested in the verso of the fragment SI 5576 which is written in Parthian language. It is well known that Middle Persian and Parthian manuscripts were usually copied at that time ( 8 th-10th cc.) by the Sogdians inhabiting Eastern Turkestan. Therefore it is possible that we are dealing with a personal note which has been left by a Sogdian speaker who copied this Parthian text or by the owner of the manuscript.

The text preserved in the fragment M 4590 (T II D 31) belonging to the Berlin Turfan Collection preserves three paragraphs. Each paragraph consists of three writing lines starting with the participle nys ' $r$ ' $d$ "begun",22 which is followed by the titles of the hymns: $m h r$ ' $y$ w'd jywndg "hymn to The Living Spirit" (1. 3), hymn at the melody pd bgr'štygr (the Righteous God, i.e. The Father of Greatness, the supreme Manichaean deity, 1. 6) and hymn b'm stwnyyg "hymn to The Column of Glory" (1. 9). The title of the fourth hymn (1. 12) is missing; possibly, it was the $n w g m$ ' $h$ "The New Moon", ${ }^{23}$ as its opening four letters are read as nun - waw - gimmel-mim, which might suggest a reference to the hymn addressed to Jesus. In any case, the epithet "The New Moon" can be found in hymn M 176 where it is applied to that Manichaean God or Prophet. ${ }^{24}$ The lines with titles $(11.3,6,9)$ are followed by two incomplete lines containing the initial words of those hymns. The second incomplete line of the fragment displays the letters $z$ ' $p t$ which could be the end of the passive participle *frz'pt (/*hnz'pt?) "finished"; the title of the hymn written on the previous non-saved missing

${ }^{21}$ See Sims-Williams 1981, 236.

${ }^{22}$ For phrases beginning with a word meaning "begun" or "ended" see BENKATO 2017 (I am grateful to Dr. Chiara Barbati for this reference).

${ }^{23}$ The other reading - nwg(s) [hr'fwryzdyg] see SundERMANn 1979, 131, note 221.

${ }^{24}$ Boyce 1975, 192-193. 
lines is unknown, but it was dedicated to Ormizdbag (1. 2). ${ }^{25}$ This list of the hymns shows no alphabetical order.

Both Collections, that of St. Petersburg and that of Berlin, have several fragments containing lists of Manichaean hymns which have been compiled according to different models. Among them, the best known is a two-folio fragment of the so-called Mahrnāmag "The Book of Hymns" kept in Berlin (with the inventory number M 1) and dated to the 9th c. It lists the opening lines of 55 various Middle-Persian hymns most of which are hymns devoted to the Living Soul and hymns for the souls of the dead. The principle according to which the hymns were collected remains obscure, as the alphabetic order is inconsistent; ${ }^{26}$ it might be that the hymns were listed in accordance with a liturgical sequence. ${ }^{27}$ Another list of Middle Persian compositions is kept in the Serindian Fund of the Institute of Oriental Manuscripts, Russian Academy of Sciences, with the inventory number SI 3160 (S 1). It was published by C. Salemann for the first time. ${ }^{28}$ That list contains 10 Manichaean texts to be read during the $y m g$ ' $n$ memorial days and the page opens with the statement that the list included 45 compositions. The preserved fragment lists the texts to be read during the first four memorial days: ${ }^{29}$ the titles are written in the middle of the line and are inscribed in a rhombus of four dots. Therefore, that fragment lists the compositions to be read during the memorial days.

\section{Conclusions}

Through a paleographical study, it has been possible to identify a distinctive scribal hand and, in turn, the belonging of the fragment SI 5576 and of the fragment M 4590 to the same manuscript containing a list of the hymns to be performed during the Bema feast. As a rule, Manichaean

${ }^{25}$ It is worth mentioning that in the Coptic Bema psalm 219, the Fisrt Man, i.e. Iranian Ormizdbag, also occurs together with the Living Spirit, the Righteous God, the Column of Glory and Jesus. See SMAGINA 2011, 439-441.

${ }^{26}$ See DuRKIn-MEISTERERNST 2006, XXXIX.

${ }^{27}$ See DURKIN-MEISTERERNST 2006, 171, note 50.

${ }^{28}$ See SALEMANn 1904, 1-26.

${ }^{29}$ This is a good occasion to correct a mistake made by myself while translating this document for publishing: ChunaKova 2011, 43. The four titles represented by denominative adjectives are certainly the names of these days, and by no means the titles of the compositions. 
manuscripts intended for storage were written extremely carefully including ornamented opening lines. On the contrary, the fragment kept in St. Petersburg and the fragment kept in Berlin show a very simple mise en texte: only black ink, no ornament, and, above all, a cursive script that has not been written with particular care. All these elements suggest that the manuscript was produced for personal use.

Finally, if the first word of the Petersburg fragment was indeed a note mentioning the Bema ceremony during which the hymns were to be performed, this fragment must be considered the one preceding its Berlin counterpart. The Chinese text on the recto side confirms that. The circumstance that the first hymn dedicated to Wisdom is written in more detail than the others could be explained by the fact that it was a more rare (and possibly even unique) composition, while the subsequent hymns were common in Manichaean tradition, and therefore a single line was enough for their identification.

\section{Abbreviations}

Pl. = Plate

\section{References}

BenKATo, Adam 2017: "Incipits and explicits in Iranian Manichaean Texts". In Manichaeism East and West. Ed. by Samuel N.C. Lieu and Nils A. Pedersen and Enrico Morano and Erica C. D. Hunter. Brepols Publishers, 29-42.

Boyce, Mary 1960: A catalogue of the Iranian Manuscripts in Manichean Script in the German Turfan Collection. Berlin: Akademie Verlag.

Boyce, Mary 1975: A Reader in Manichaean Middle Persian and Parthian. Texts with Notes. Téhéran-Liège. Acta Iranica 9.

Chunakova, Olga (publ.) 2011: Manikheiskie rukopisi iz Vostochnogo Turkestana: Srednepersidskie i parfianskie fragmenty / Vvedenie, transliteratsiia, perevod, kommentarii, prilozheniia O.M. Chunakovoi. Faksimile rukopisei [Manichaean Manuscripts from Eastern Turkestan: Middle Persian and Parthian fragments / Preface, transliteration, translation, commentaries, supplements. Facsimile of Manuscripts]. Moscow: Izdatel'skaia firma Vostochnaia literatura.

Chunakova, Olga 2015: Novyi parfianskii manikheiskii fragment [A New Parthian Manichaean fragment]. Pis'mennye pamiatniki Vostoka. No. 2(23), 59-64.

Durkin-Meisterernst, Desmond 2004: Dictionary of Manichaean Middle Persian and Parthian: Brepols Publisher. Corpus Fontium Manichaeorum: Subsidia. Dictionary of Manichaean Texts, vol. III: Texts from Central Asia and China. Ed. by Nicholas SimsWilliams, Part 1.

Durkin-Meisterernst, Desmond 2004a: “The Parthian mwqr'nyg b'š'h” (Turfan Collection, Berlin, M 4a I V 3-16). ARAM Periodical. 16, 95-107. 
Durkin-Meisterernst, Desmond 2006: The Hymns to the Living Soul. Middle Persian and Parthian Texts in the Turfan Collection. Berliner Turfantexte, 24. Turnhout: Brepols Publishers.

DurKIN-MeIsTERERnst, Desmond 2007: "Aramaic in the Manichaean Turfan Texts". In Iranian Languages and Texts from Iran and Turfan. Ronald E. Emmerick Memorial Volume. Ed. by Maria Macuch and Mauro Maggi and Werner Sundermann. Wiesbaden: Harrassowitz Verlag, 59-74.

Gulácsi, Zsuszanna 2005: Mediaeval Manichaean Book Art. A Codicological Study of Iranian and Turkic Illuminated Book Fragments from 8th-11th Century East Central Asia. Brill Publisher.

HENNING, Walter B. 1936: "Ein manichäisches Bet- und Beichtbuch". Abhandlungen der Preussischen Akademie der Wissenschaften. No. 10, 3-143.

Henning, Walter B. 1943: "The Book of the Giants". Bulletin of the School of Oriental and African Studies, 11, 52-74.

Khosroyev, Alexander 2007: Istoriia manikheistva (Prolegomena) [The History of Manichaeism (Prolegomena)]. Sankt-Petersburg: Filologicheskii fakul'tet Sankt-Peterburgskogo gosudarstvennogo universiteta.

Morano, Enrico 2017: "Manichaean Sogdian Poems". Corpus Fontium Manichaeorum. Analecta Manichaica I. Manichaeism East and West. Ed. by Samuel W.C. Lieu in association with Erica C.D. Hunter, Enrico Morano, Nils A. Pedersen. Turnhaut: Brepols, 171184.

ReITZENSTEIN, Richard 1921: Das iranische Erlosungsmysterium. Religionsgeschichtliche Untersuchung. Bonn: A. Markus and E. Weber's Verlag.

SALEmANN, Carl 1904: Ein Bruchstück manichäischen Schrifttums im Asiatischen Museum. Izvestiia Imperatorskoi Akademii Nauk. T. VI, No. 6. Sankt-Petersburg, 1-26.

Sims-Williams, Nicholas 1981: "The Sogdian fragments of Leningrad". Bulletin of the School of Oriental and African Studies, 44, 231-240.

Sims-Williams, Nicholas and Durkin-Meisterernst, Desmond 2012:. Dictionary of Manichaean Sogdian and Bactrian. Turnhaut. Corpus Fontium Manichaeorum: Subsidia: Dictionary of Manichaean Texts; 3: Texts from Central Asia and China; 2.

SMAGINA Evgeniia 2011: Manikheistvo po rannim istochnikam [Manichaeism on earlier sources]. Moscow: Izdatel'skaia firma Vostochnaia literatura.

SUNDERMANN, Werner 1973: Mittelpersische und parthische kosmogonische und Parabeltexte der Manichäer mit einiger Bemerkungen zu Motiven der Parabeltexte von Friedmar Geissler. Berliner Turfantexte, 4. Berlin: Akademie Verlag.

SundERMANN, Werner 1979: "Namen von Göttern, Dämonen und Menschen in iranischen Versionen des manichäischen Mythos". Altorientalische Forschungen. VI, 95-133.

WidEngREN, Geo 2001: Mani i manikheistvo [Mani and Manichaeism]. Transl. from German by S.V. Ivanov. Sankt-Peterburg: Izdatel'skaia gruppa Evrasia. 